\title{
The issue of alcohol abuse among the youth - students of Lublin schools
}

\begin{abstract}
Introduction. Alcohol abuse among the youth is a pressing social issue. It is not only related to one's individual susceptibility to risky or harmful drinking but also the issue of one's family living with the individual that abuses alcohol. It needs emphasizing that alcohol consumption is on the rise and the age at which young people have their first alcoholic drink is declining as well. Also, girls tend to drink as much as boys.

Aim. The aim of this work was to investigate the issue of alcohol abuse among young people of school age and the relationship between the following variables: school educational level, sex, satisfaction with home life and drinking patterns.

Material and methods. The authors interviewed some 1444 students of 32 schools (12 elementary schools, 10 junior high schools and 10 high schools) chosen at random, using an anonymous questionnaire. The collected data were analyzed statistically, taking the following factors into consideration: sex, school level, atmosphere at home.

Results and conclusions. One's sex, school level and satisfaction with home life had influence over the respondents' answers concerning alcohol consumption. The research study shows that students of schools at all levels drink alcohol - high school students drink vodka, junior high school students (gimnazjum in Polish) prefer beer, while elementary school students, who tend to drink the least, prefer wine. Interestingly enough, boys are drinking more than girls, yet girls are more likely to try all types of alcohol. Children who reported good atmosphere at home are less likely to drink, while in case of troubled homes, only every eighth respondent does not drink. The atmosphere at home also affects one's drinking habits. Most of the respondents have no idea about ways of helping people addicted to alcohol.
\end{abstract}

Keywords: alcohol abuse, alcohol, school-aged youth.

DOI: $10.1515 /$ pjph-2016-0001

\section{INTRODUCTION}

National Health Programme is a document that takes into account the main directions for health policy and makes it possible to implement measures related to social health. In order to implement the guidelines of National Health Programme into reality, both the government administration and non-governmental organizations should take part, as well the local authorities, communities or citizens. Improving Poles' health and quality of life requires a joint effort, both on the side of community organizations and local governments. Healthy people are more likely to care about their own development or selfrealization, as well as they are more flexible to various social changes that appear. A healthy society that appears in consequence is a guarantee of both social and economic development of the country. As the document says, "Reducing alcohol consumption and changing its structure, and mitigating health damages caused by alcohol consumption" [1-3] is one of the main goals of the National Health Programme.

The age at which young people have their first drink is decreasing - high school, junior high school or even elementary school students do use alcohol. Initially, alcohol use patterns include risky drinking which causes no harm to health, yet it is accompanied by risky behaviors. Later on, harmful drinking appears which means some real health problems, like liver stetatosis, an increase of the value of liver enzymes (APAT, ALAT, GGTP). A fully symptomatic alcohol addiction usually appears after reaching maturity [4-7].

\section{AIM}

The authors investigated the issue of alcohol abuse among school-aged youth, as well as the influence of the following factors: sex, school level, atmosphere at home over one's alcohol drinking patterns.

\section{MATERIAL AND METHODS}

The authors of the study interviewed students attending public schools of all levels, located in Lublin: primary, junior high and high schools. The study was supposed to 1. determine drinking levels among the students of Lublin schools, 2. establish, whether there is a need for any alcohol-related prophylactic actions, 3. determine students' awareness about support programs (organizations that help individuals experiencing drinking problems). 
The study was conducted on a randomly chosen group of 1444 students of 32 schools (12 primary schools, 10 junior high schools and 10 high schools). An anonymous survey was used for the study. The collected data were then analyzed statistically, looking at 1. sex, 2. school level, 3. atmosphere at home. Girls constituted over a half of the respondents $(55.9 \%$ of the study respondents were girls and $43.5 \%$ boys). Most high school students were girls $(59.2 \%)$, while the lowest number of girls was reported in elementary schools $(51.6 \%)$.

Some 1242 questionnaires ( $86 \%$ of participants) were correctly filled out. This group comprised of 466 elementary school students (year 6), 340 junior high school students (year 3 ) and 440 high school students (year 2), which stands for $37.4 \%, 27.2 \%$ and $35.4 \%$ of all the respondents.

\section{RESULTS}

\section{Lublin school students and alcohol drinking}

Some $53.8 \%$ of the respondents provided a positive answer to the following question "Do you drink alcohol?" Looking at schools of various levels, it appears that most high school students drink alcohol (89.3\%). In case of junior high schools, some $65.7 \%$ of students admitted to drinking, whilst in primary schools it was $11.7 \%$. Even though the last result is quite low, it is disturbing, when taking the respondents' age into consideration.

The authors' research shows that girls are slightly more likely to drink than boys. The actual numbers were as follows - some $58.1 \%$ of the respondents were girls and $48.9 \%$ were boys. Most students completing the questionnaire claimed that they "sometimes" drink alcohol, yet these are mostly girls rather than boys ( $52.2 \%$ vs $40.9 \%)$. Furthermore, boys claimed that they drink "often" ( $8 \%$ and 5.9\% respectively) (Table 1$)$.

Taking into consideration „Atmosphere at home" some interesting conclusions might be drawn. In case of homes, where the atmosphere is good, where children can share their

TABLE 1. Gender differences in alcohol use.

\begin{tabular}{lccccc}
\hline \hline & & \multicolumn{3}{c}{ Alcohol consumption } & \\
\cline { 3 - 5 } & & $\begin{array}{c}\text { I drink } \\
\text { often }\end{array}$ & $\begin{array}{c}\text { I drink } \\
\text { sometimes }\end{array}$ & $\begin{array}{c}\text { I do not } \\
\text { drink } \\
\text { at all }\end{array}$ & Total \\
\cline { 3 - 5 } & Boys & 8.0 & 40.9 & 51.1 & 100 \\
\cline { 3 - 5 } Sex & Girls & 5.9 & 52.2 & 41.9 & 100 \\
\hline Total & & 6.8 & 47.2 & 45.9 & 100 \\
\hline
\end{tabular}

TABLE 2. The relationship between relationships at home and drinking.

\begin{tabular}{lccccc}
\hline \hline & & \multicolumn{3}{c}{ Alcohol consumption } & \multirow{2}{*}{ Total } \\
\cline { 2 - 5 } & & $\begin{array}{c}\text { I drink } \\
\text { often }\end{array}$ & $\begin{array}{c}\text { I drink } \\
\text { sometimes }\end{array}$ & $\begin{array}{c}\text { I do not } \\
\text { drink at all }\end{array}$ & \\
\cline { 2 - 5 } & & $\mathbf{\%}$ & $\mathbf{\%}$ & $\mathbf{\%}$ & \\
\hline \multirow{2}{*}{$\begin{array}{l}\text { Relationships } \\
\text { at home }\end{array}$} & b) & 4.6 & 37.7 & 57.7 & 100 \\
\cline { 2 - 5 } & c) & 7.5 & 56.3 & 33.9 & 100 \\
\cline { 2 - 5 } & d) & 29.2 & 58.3 & 12.5 & 100 \\
\hline Total & 6.9 & 47.1 & 46.0 & 100 \\
\hline
\end{tabular}

problems with parents, the school-aged youth are less likely to drink alcohol. The respondents that concern their family home a safe haven, where they can share their problems with parents, counting on their understanding, over a half of the respondents do not drink alcohol (57.7\%). On the other hand, in case of homes where there is a family conflict, every eighth respondent does not drink alcohol. Both of the following groups are the most common - those who drink "frequently" (29.2\%) and "sometimes" (58.3\%) (Table 2).

Most respondents pointed to beer as beverage their drink the most (answering the question What type of alcohol do you drink), whilst vodka and wine are less popular $(90.2 \%, 61.4 \%$ and $53.1 \%$ respectively.) Students of all school types admitted that they drink all types of alcohol, although high school students are most likely to do so. They declared they drink vodka most (67.7\% of the respondents), as well as wine and beer $(62.3 \%$ and $59.7 \%$ respectively.) Almost every third junior high school student uses all types of alcoholic beverages, even though they tend to drink beer most (33.4\% of the respondents).

The fact that elementary school students drink alcohol is highly disturbing, especially concerning the fact that they mostly drink wine, as well as beer or even vodka $(8.3 \%, 6.9 \%$ and $2.9 \%$ respectively). Girls are more likely to try different kinds of alcohol, which is particularly visible in case of wine that girls seem to have a preference for $(63.8 \%$ of female respondents vs $36.2 \%$ of male respondents,). In case of other types of alcoholic beverages, the proportions change - some $60.1 \%$ of girls declare that they drink beer (against $39.9 \%$ of boys) and $58.6 \%$ admit to drinking vodka (against $41.4 \%$ of boys) (Table 3 ).

There is a strong relationship between the tendency to drink and relationships at home. Those respondents who gave positive opinions about the relations at home are most likely to use alcohol, especially beer (44.1\%), while vodka is the least popular choice $(38.4 \%)$. Conversely, those respondents who claimed that they have negative atmosphere at home are least likely to use alcohol. In this group, some $3.3 \%$ of the respondents drink beer or wine, while some $3.9 \%$ drink vodka (Table 4 ).

TABLE 3. Gender differences in terms of alcohol consumption patterns.

\begin{tabular}{lcccc}
\hline \hline & & \multicolumn{3}{c}{ Type of alcohol } \\
\cline { 3 - 5 } & & Beer & Wine & Vodka \\
\cline { 3 - 5 } & Boys & \% & \% & \% \\
\cline { 3 - 5 } Sex & Girls & 60.9 & 36.2 & 41.4 \\
\hline \multirow{2}{*}{ Total } & & 100 & 63.8 & 58.6 \\
\hline
\end{tabular}

TABLE 4. The relationship between the atmosphere at home and the kind of alcohol that one drinks.

\begin{tabular}{lcccc}
\hline \hline & & \multicolumn{3}{c}{ Kind of alcohol } \\
\cline { 2 - 5 } & & Beer & Wine & Vodka \\
\cline { 2 - 5 } & & $\mathbf{\%}$ & $\mathbf{\%}$ & $\mathbf{\%}$ \\
\hline \multirow{2}{*}{$\begin{array}{l}\text { Relationships } \\
\text { at home }\end{array}$} & a) & 34.1 & 41.4 & 38.4 \\
\cline { 2 - 5 } & c) & 19.7 & 35.4 & 36.0 \\
\hline c) & d) & 3.3 & 3.3 & 21.7 \\
\hline Total & 100 & 100 & 100 \\
\hline
\end{tabular}

a) My home is a place where I feel safe and I can share all my problems to parents and they understand them.

b) Even though I consider my home a safe haven, I do not feel confident enough to tell parents about all my problems.

c) I consider my home a safe haven, yet I do not want to talk to my parents about my problems.

d) My home is a place where I experience various unpleasant situation and I cannot be on the same wavelength as my parents are. 
The authors also investigated students' knowledge about support organizations working in Lublin Are there any alcohol support services in Lublin? Less than every third respondent provided a positive answer $(29.8 \%)$, others said ,no" or provided an enigmatic answer ,I have no idea" (2.1\% and $67.8 \%$ respectively.) High school students (38.1\%) are most likely to know such organizations, while elementary school pupils $(20.1 \%)$ are least likely to know about these services. They are least likely to use alcohol, so this number shows that they have a relatively huge knowledge about the issue.

TABLE 5. Students' knowledge about support organizations working in Lublin.

\begin{tabular}{lccccc}
\hline \hline & \multicolumn{4}{c}{$\begin{array}{c}\text { Are there any alcohol support } \\
\text { services in Lublin? }\end{array}$} & \multirow{2}{*}{ Total } \\
\cline { 3 - 5 } & & Yes & No & $\begin{array}{c}\text { I have no } \\
\text { idea }\end{array}$ & \\
\cline { 3 - 5 } & & $\mathbf{\%}$ & $\mathbf{\%}$ & $\mathbf{\%}$ & \\
\hline \multirow{3}{*}{$\begin{array}{l}\text { Type of } \\
\text { school }\end{array}$} & Elementary & 20.1 & 1.7 & 78.2 & 100 \\
\cline { 2 - 5 } & Junior high & 33.5 & 3.9 & 62.6 & 100 \\
\cline { 2 - 5 } & High & 38.1 & 1.2 & 60.7 & 100 \\
\hline Total & 30.1 & 2.1 & 67.8 & 100 \\
\hline
\end{tabular}

Almost all respondents (97\%) claimed that there are support services for people addicted to alcohol in Lublin. They claimed that these organizations mainly deal with arranging meetings with psychologists, promoting healthy lifestyle, as well as providing advice about social, psychological and health consequences of being addicted. Only every tenth participant $(11.4 \%)$ was able to name these organizations. Most respondents (92.3\%) knew Alcoholics Anonymous (Ruch Anonimowych Alkoholików in Polish), while some 1.4\% mentioned Municipal Family Support Center (Miejski Ośrodek Pomocy Rodzinie in Polish).

\section{CONCLUSIONS}

Overall, the following factors influence respondents' answers concerning using alcohol: school level, gender or satisfaction with relationships at home. It is mainly high school students that use alcohol. They lead the statistics of "frequent" and "occasional" drinking. The fact that both junior high and elemenetary school students "sometimes" use alcohol is highly disturbing. There is a close relationship between the school level and the type of alcohol that one drinks. High school students prefer vodka, junior high school students admit to beer drinking, while elementary school students tend to drink wine. The older the students are, the more alcohol they drink. Most of the study respondents (elementary school students in particular) have no idea about the alcohol support organizations.

When it comes to gender differences, boys drink alcoholic beverages more frequently than girls, yet the latter are more likely to use different kinds of alcohol. This is apparent in case of wine, as well as beer or vodka. By the way, boys are most likely to drink vodka.

Looking at the "atmosphere at home" factor it appears that the youth assessing their atmosphere at home as "good" is less likely to drink. Among those claiming that they deem their family home a safe haven, almost a half does not use alcohol at all. In case of homes where the atmosphere is worse, only every eighth respondent does not drink alcohol.
Interestingly enough, the respondents claiming they have a good atmosphere at home are most likely to use all kinds of alcohol - they are most likely to drink beer and least likely to choose vodka. In addition, the respondents that have negative opinions about the atmosphere at home are most likely to choose vodka.

\section{REFERENCES}

1. Narodowy Program Zdrowia na lata 2007-2015, Załącznik do Uchwały Nr 90/2007 Rady Ministrów dnia 15 maja 2007 r.

2. Rocznik Statystyczny 2008 oraz Rynek Wewnętrzny 2007 (publikacja elektroniczna GUS).

3. Sygit M, Sygit B. Problemy zdrowia publicznego w polityce zdrowotnej Państwa Polskiego. Zdr Publ. 2003;3/4(113).

4. Bilikiewicz A. Psychiatria. Warszawa: Wydawnictwo Lekarskie PZWL; 2004.

5. Cekiera C. Ryzyko uzależnień. Lublin: TN KUL; 2001.

6. Sierosawski J. Płeć a wzory picia. [http://www.swiatproblemow.pl/2010 12 1.html]

7. Uzależnienia w doświadczeniach lubelskiej młodzieży. Diagnoza zjawiska.Wydział Zdrowia i Spraw Społecznych urzędu Maista Lublin w ramach GPPiRPA w roku 2009. Lublin; 2009.

Corresponding author

Anna Jurek

1 Chodźki Str, 20-093 Lublin

E-mail:zdrowie.publiczne@umlub.pl 